\title{
Suspending New Testament: Do the Two Talmuds Belong to Hermeneutics of Texts?
}

\author{
Sergey Dolgopolski
}

University at Buffalo, SUNY, the United States of America

e-mail: sergey@buffalo.edu

Abstract: The paper explores the role of competing notions of what does it mean to have a testament of the law of the past in Christian and Rabbinic corpora of text and thought. The argument probes and renegotiates the complex relationships of the Christian suspension of Old Testament by the New Testament and the Rabbinic suspension of (any) new testament in the two Talmudim. It consequently draws implications of that analysis for understanding the relationships of the two Talmudim to the tradition of hermeneutics of texts, as influenced as the latter has been by theological and literary approaches of various Christian theologies of the two Testaments. As a part of that analysis the articles justifies the task of advancing and providing a critique of political theology and political philology as modes of thought and investigation. That provides a way to ask anew the question about relationships between theology, literary theory, and political thought.

Keywords: Old Testament, New Testament, Palestinian Talmud, Babylonian Talmud, theology, suspension, cancellation, hermeneutics of texts, literature, formal logic, Aufhebung, Auerbach, Kafka, political philology, political theology, political thought, literary theory, critical theory.

\section{Introduction ${ }^{1}$}

New Testament (NT) suspends Old Testament (OT), a (Christian) theologeme ${ }^{2}$ teaches us. Can thinking about Rabbinic literatures through a comparative lens with theology help, once again, to understand rabbinic texts better? This time, that means to revisit the ways the characters in the two Talmuds approach the Mišnah and the apocrypha (barayt'a, in Medieval Talmudic parlance) they ascribe to Mišnahic sages? Guided by this question, I retrieve a parallel (Rabbinic) theologeme. In this 
theologeme, any attempt at any new testament, i.e. at any new testimony or witness presenting the (divine) law in the form of a rule becomes programmatically suspended, in a variety of ways in which such suspension works.

By a necessity to which the argument below attends, navigating the two general theologemes of suspension - the suspension of OT in NT and the suspension of (any) new testament - leads to rethinking the role of, and to repositioning, the two Talmuds in relationship to the tradition of hermeneutics of texts. Additionally, that program of research leads to the task of reevaluation of the position of formal logic in relation to hermeneutics of texts; even if, in this essay, I would only be able to gesture towards this last element of equation.

At the same time and by the same token, the task of situating the two Talmuds vis-à-vis hermeneutics of texts involves yet another task: to situate the tradition of hermeneutics of texts vis-àvis what I will introduce first as a theology of suspension, and secondly, and as I will claim, more fundamentally, as a philology of suspension.

The suspension in question articulates itself first of all in political theology ${ }^{3}$ as a way of thinking, which invariably and by its very definition draws on the suspension of the OT in the NT. But this suspension articulates itself once again in rabbinic literature, and this time rather differently: it emerges as a suspension of any new testament (in general, i.e.) - and by extension as the suspension of any testament and/or witness to the divine or any other version of law. Crucially for my argument below, suspension of any new testament articulates in two different ways in the two corpora of rabbinic literature, dubbed as these corpora were from the middle ages and on, the Palestinian and Babylonian Talmudim.

My main claim in articulating that more general suspension of any testimony/witness/testament to a law in the form of a rule is that in suspending any (new) testament to the law, at work is a political philology or, as I will soon explain in more details, an analysis applying the powers of philology (Gumbrecht) to understand the political relationships between parties. Political philology sees the relationships expressed in philological forms as never transparent to the parties these forms involve, create, or presume. For a quick example of a political philology, for a devotee of NT, NT is coming from and is cancelling/suspending OT; however, despite on what that devotee can accept, the idea that there is OT is an effect, a result, and an outcome of an idea that there is NT. There can be no OT without NT having already emerged. NT thus both follows from and precedes OT. Political philology explores this inversion of cause and effect, ${ }^{4}$ as well as other inversions in the texts and thought processes philology is a study of. As I will explain below, political philology also enables a way of looking at the two Talmuds, which precedes, grounds, embraces, and escapes political theology as a hitherto predominant way of thinking suspension in Christian theology and beyond - the suspension of OT by NT.

Of course, the characters in the Talmuds suspend a different (new) testament, the Mišnah, the apocryphal testaments of the rules of the law (the Toseft' $a$ and the Barayt' $a$,) or perhaps even the Scripture and/or prophesy; and they do so in a different way as compared to Christian theologeme of suspension. That means not in the way of allegory or, and in particular, of prefiguration; but rather in a variety of other ways, which I can describe - preliminary and generally, but perhaps still usefully as a starting point - as refutations. That general description allows, at the very least, to begin laying out the complex claim, which will be of primary concern in this essay. It is the claim that political philology precedes grounds, embraces, and escape political theology as a way to think the suspension.

Justifying the necessity of, and evaluating, such complex claim will involve several steps; and these steps must be taken from necessary different starting points. I will thus proceed step by step, and starting point by starting point. 


\section{Starting Point One: Is Talmud Literature? A Philological Question}

We live, Erich Auerbach teaches us ${ }^{5}$, in the world - or in the 'reality,' in his terms - which is 'represented' in literature. Speaking in his terms again, that means European literature both images and shapes that 'reality' or that world. In light of Auerbach's analysis of that representation of reality in Western literature, it however also means an almost impossible combination of a facade of the present, famously exemplified in Auerbach by Homer, with the faceless depth of the past, exemplified for him by Mosaic Scripture. Of the faceless depth of the past, the Mosaic scriptures registers only what is significant for the future of the reader. In contrast, of the facade of the present, Homers lets nothing escape. To rephrase Auerbach's argument in terms of style, the Mosaic Scripture never styles the faceless past as praesens historicum. That for Auerbach is a strong contrariety to the Homeric facade of the present, the on-going front-stage of action, in which nothing hides in background. The Homeric verse never goes beyond - neither behind nor before the facade; the Mosaic Scripture never puts the reader face-to-face with the past the Scripture accounts for. That contrariety between the face or facade of the present and the faceless depth of the past is radical, for Auerbach; and if taken in separation from one another, neither Mosaic Scripture nor Homer's poems are pieces of literature yet, for him. However, when Scriptures and Homer are combined and read as and through figurae, i.e. as descriptions and shapes that deviate from the typified, standard, normalized, or predictable facade of the things, European literature begins. ${ }^{6}$ It then occupies, and indeed erects, the stage - the 'reality' and the world. What that means however is that we, for Auerbach, are always already the children of that difficult marriage between the facade of the potentially insignificant but always entertaining present on the one hand and the outmost significance of the depth of faceless past, on the other hand. That also means figurae are ways of doing impossible, of employing Homer's style to face the faceless but allsignificant past from which Scripture comes.

Rabbinic literature is an example of such a difficult marriage. In rabbinic exegesis of Scripture (in midrašey haggadah ${ }^{7}$, in contemporary Talmudic parlance) an implied reader is provided with competing interpretations of Mosaic Scripture to complement the latter with praesens historicum they do not contain. It thus creates a facade, praesens historicum, in the places in Scripture where a reader is initially finding nothing but an account of the significance of the past. In such exegesis, the reader thus ascends to a facade from behind, from the faceless depth, which becomes a 'background' event, as the exegesis re-styles the past as praesens historicum, as fictive as it may be.

In an exactly opposite, and thus similar way, in rabbinic isogesis of Scripture (in midrašey halakah, in contemporary parlance) a reader faces the depths of the faceless past of the Scripture by approaching the latter with his or her own question. The reader is to approach a scripture with her present concern, point of view, or opinion, all formulated as almost rhetorical questions, to which the verses of Scripture provide answers to become 'obvious' from now on. In isogesis, the scripture, then, is mobilized to correct or even refute an answer the reader initially anticipates.

Both modes suspend the faceless depth of the past in the Scripture by converting into a praesens historicum and by gesturing to the limits of such conversion. In both exegesis and isogesis, the reader moves between the facade and the faceless past, ascending from behind the facade, as she is in the exegesis; or descending beyond the facade, as she is in the isogesis of Scripture. In either way, the reader moves along the path of suspension.

In this discussion, I left aside the question of comparison between this and the principles of allegory and pre-figuration, which Auerbach addresses explicitly in his analysis of the 'scenes from the drama of European literature ${ }^{8}$ where Christian theology of prefiguration and emergence of "Western literature' go hand to hand (in a way, similarly to how politics and theology go hand to hand in Carl Schmitt and related authors) and where one finds no mention of rabbinic literatures or modes of thought. 
Instead, as heuristically inspired by Auerbach as the analysis in this essay remains, at the center there still stays the role of Mosaic style as one of the two conditio sine qua non for the 'European literature' to emerge and develop. In that light, the question of the two Talmuds and of the tradition of hermeneutics assumes the following form: how, and indeed whether, the two Talmuds can find a place in the perspective Auerbach's work is drawing? Where do the two corpora of text and thought dubbed, as they have been from Middle ages and on, the Yerušalmi and Bavli or Palestinian and Babylonian Talmuds respectively - belong on the scope of the emergence and development of 'Western literature' and to the hermeneutics of texts as a part thereof?

I have paused briefly for the dubbings because they have their power of framing. That power translates in presuming that each of the two Talmuds is an internally coherent body of thought. That presumption is yet to be justified or denied in each case, and the outcomes of such justification or denial are to be taken seriously. Yet the presumption was heavily at work beginning from the Medieval view of the Bavli as internally coherent tractate of tractates. It continued to work in Luzatto's view of the Bavli as the arch-paradigm of European Enlightened reason. Furthermore, projecting that assumed literary-intellectual integrity of the Bavli back onto the Yerušalmi informed how the Yerušalmi was both learned traditionally and studied academically. This perception of integrity is important for this essay in one respect only: in how such a perception of the Bavli informs both traditional and scholarly approaches to the Yerušalmi. The two Talmuds become shadows of each other. One approaches the Yerušalmi with the set of habits and expectations formed in one's reading the Bavli as a starting point, resulted in finding many contrasts between the two Talmuds. Alternatively, one considers the Yerušalmi the beginning, and the Bavli a logical continuation of the same work or of the same way of thinking, as Mišnah-centric as both of the Talmuds are assumed to be on that approach. For the purposes of and within the limits of this essay, I can only say that one has to keep this power of framing of corpora of rabbinic literature as two largely coherent 'Talmuds' in a constant check.

I now come back to the main line of inquiry. I address the question of the placement of the two Talmuds vis-à-vis the traditions of hermeneutics of texts both in light and despite Auerbach's perspective.

I do so through a case study. That case study involves both a slow reading of two parallel texts from the two Talmuds and a very broad and therefore very preliminary mapping of these two texts visa-vis two competing paradigms in hermeneutics of texts. That would mean, in particular, that both 'hermeneutics' and 'texts' would need to be accessed in terms of whether they belong to 'European literature' in Auerbach's sense.

The first of the two paradigms of hermeneutics refers back to Aristotle's Peri Hermeneias; the second, to use his name as a synecdoche, to Schleiermacher's approach to interpreting both Homer and Bible in a hunt for the original intent of the assumed authors of these ancient compositions.

In broadest terms, Aristotle associates hermeneutics with prudence, or a reasonable action in view of the future that cannot be known. He locates the task of hermeneutics in the realm of what is possible as opposed to what is necessary or impossible, thus linking hermeneutics to rhetoric. He therefore associates that realm of the possible with the future, for the past for him has already taken place, can be known, is already determined, and thus, at least in principle, leaves no truly open possibilities. The future, however, is prone of possibilities, and therefore - unlike past - cannot be known. The task of the hermeneutics is the future. The question hermeneutics addresses is how to act prudently at a point of time based on as many possible futures, and thus on as many indeterminacies, as the fact of having many possibilities might involve. Hermeneutics is first of all about the possible, and about prudent action vis-a-vis the unknown play of possibilities in the future.

In contrast, in an equally broad if not in an even broader scope, Schleiermacher's hermeneutics of both Homer and Bible is directed towards the past, which Schleiermacher, like Aristotle, interprets as always determined, even if, unlike Aristotle, neither initially understood, nor unproblematic if one 
wants to attain its understanding. The task of interpretation for Schleiermacher is to understand that past, and in particular the 'historical' author's intention residing there. That presumes this task to be hard but doable, of course if proper philological, linguistic and cultural methods of interpretation are applied.

Despite an obvious contrast between hermeneutics of Aristotle and Schleiermacher, there is a common denominator. For both, the past is, arguably, a fait accompli. To come back to Auerbach's facade of the present and the faceless depth of past, both Schleiermacher and Aristotle remain on and only on Homer's side of equation, and thus outside of the full scope of 'Western literature.'

Hermeneutics is not quite literature, as it follows therefrom. What that means, however, is that both rabbinic exegesis/isogesis and - at least hypothetically - the two Talmuds do not belong to the tradition of hermeneutics of text, either. In the pages below I will test that hypothesis through first presenting results and then performing a slow reading of two parallel texts from the two Talmuds.

Allow me yet another pause here in order to explain another necessity of engaging with the question of the role of the tradition of hermeneutics of texts in relation to literature. This time it is an internal necessity that arises from the perspective of the discipline of Rabbinics, the academic study on rabbinic corpora. At this point, the question is: Why problematize hermeneutics of texts when approaching the Talmuds? An answer is two-fold.

Firstly, the academic study on the Talmuds has so far relied on empirical philology (i.e. 'curatorship of texts,' Gumbrecht ${ }^{9}$ ) at the expense of taking for granted what these texts are as a body of thought. This is where the above observation about dubbing the corpora as two Talmuds becomes relevant. It exemplifies how 'taking for granted' that the two Talmuds is a framing notion, informs how these - in fact much more multiple - bodies of text and thought have been approached. Such a framing approach to a corpus of texts and thought as if they were two Talmuds strongly informed academic scholarship on the Talmuds in the long 20th century. On that approach, one is not permitted to access any 'logic' and/or 'hermeneutics' of the 'thought' in the Talmuds without first committing text criticism. The argument goes along the lines of a pseudo-rhetorical question 'What kind of conclusions about the 'logic' or 'hermeneutics' at work in the texts of the Talmuds can one derived if these texts are not established reliably enough on empirical philological grounds of text criticism?' That implied hermeneutical distinction between 'text' and 'thought,' let alone the framing of the 'two Talmuds' in which it comes, already suffices to explain the internal urgency of the question of the relationships between hermeneutics of text and the study of the two Talmuds.

Secondly, and thinking further with and about this approach, text-criticism's deferral of analyzing 'thought' until such time when the 'text' is established is not problem-free in hermeneutical terms either. It is both heavily and tacitly based on a certain version of hermeneutics, which even if not found ' $i n$ the text' as it were, still informs the approach of a text-critical scholar 'to the text.' The very separation of the two bodies, the body of text and the body of thought is a hermeneutical principle, an inheritance of Schleiermacher's hermeneutics of classical texts, where thought was located in the outside of the text, in the past mistakenly controllable, - and by the same token effaced by the facade of the present historicum. More specifically, as already explained, that effacement of the faceless depth of the past took place in and by the authorial intent, which Schleiermacher's interpretation was seeking to restore behind the 'text' or its 'language.'

A problem is that together with this separation of 'text' and 'thought' came an automatically and thus uncritically - accepted view on the very way in which texts can mean, as non-literary as, in Auerbach's terms, that mode of meaning can get. What is more, this hermeneutical, i.e. non-literary, view has been accepted even before, and as a foundation of how, any particular meaning of a given Talmudic text was approached via procedures of text criticism, as hermeneutical as they therefore were.

With this in mind, the case study can help questioning that very hermeneutical - rather than literary - assumption about how texts mean. Part of that assumption was that texts mean Platonically 
and/or Socratically; that is to say non-literary in Auerbach's terms; rather than, for example, along the lines of Mosaic approaches to meaning as being both definitive of the future and inexpressible as a present.

Without jumping ahead of myself, I can only say about the case study of slow reading below that in the framework of comparison between the traditions of the two Talmuds, of 'literature,' in Auerbach's sense, and of hermeneutics in Schleiermacher's sense, the temporality in the two Talmuds contrasts both Homeric and Mosaic one. That temporality entails, at the very least, a very unusual sort of 'literature' i.e. of combination of Homer and Moses, in Auerbach terms.

That 'literature' of the two Talmuds reverses Aristotle's prudence to think about the past that can never be fully known. Instead the past is only partially available through the record of its tradition, and getting to its significance requires not only a prudent reading, now directed to the past, but much more. That reversal also applies to intention, the main concern of modern hermeneutics. Even if intention remains of a concern, it also belongs to the past that can never be fully known, not because it is of multiple possibilities, but because it is fundamentally faceless. This is why prudence, even directed to the past, proves insufficient. That means, intention can no longer control the powers of philology.

Even more specifically, it means, as the case-study will help to exemplify, that the location of prudent action towards the past changes. The task is no longer to 'interpret' (in Aristotelian sense, i.e. almost to divinate in order to act prudently in view of future that can never be fully known). Instead, the task is to probe the record of tradition without necessarily committing to any praesens historicum, that tradition might be misconstrued to entail. ${ }^{10}$

In terms of the case-study below, and also more generally, that difference in where the prudent actions locates - in the past or in the future - has implication for the role of understanding. In modern hermeneutics, understanding of the past is reachable in the same way in which the knowledge of the future was for Aristotle. Understanding the past can be attained with prudence applied in reverse direction - the modern hermeneutics contents - if one advances to the past not right away but through initial step or steps of a carefully cultivated non-understanding. In contrast to that, the Talmud's treatment of the traditional records of the past insists on a temporality of refutation, which draws on the necessity of ultimate failure or 'self-refutation' found in the argument of another person. Finding such a failure becomes the only authentic way to approach faceless past.

A parallel to that in modern hermeneutics would be non-understanding as the end of hermeneutical process. Yet this parallel is not full on at least two accounts: refutation is to fail the other interpretation (without insisting on the correctness or even on existence of any 'successful' one); and, as a result, a 'hermeneutical' process in the Talmud is never lonely: there is no one subject who interprets - neither an individual nor collective subject (for a nation, for example, can be as lonely as an individual subject, and can too be an agent of hermeneutical process). In that, to speak in advance one last time, refutation of the other and indeed of a tradition becomes a way to encounter the faceless past to which Schleiermacher's hermeneutics might not have any access.

In what follows I explore no more but also no less than one particular way of that encounter with the faceless depth of past, the way of suspending the traditions deemed to have come from that past and to have captured the law in a set of rules.

To highlight yet another important implication of this attempt: It has a bearing for the question of the role formal logic plays as a way to think of the hermeneutics of texts. That has to do with how different Auerbach's 'literature' is - not only from hermeneutics but also from logic. If one follows Auerbach in granting literature the two irreconcilable elements, the faceless depth of the past and the facade of the present brought forth in an explicitly stated language of foreground, then any attempt at a formal logic, however much constrained by the theorem of non-fullness of any formalization, places logic and literature as not only mutually exclusive but also mutually necessary. It is only once the 
faceless depth of the past becomes unavoidable in reading a language that one can conceive a necessity to develop a different language, a language fully controllable by calculation. It is therefore only in response to such an encounter with the faceless past that formal logic takes shape. Logic thus becomes the most authentic alternative to the 'literature,' and thus logic can only come into view when 'literature,' and not merely Mosaic Scripture, is around. Homer alone, and even Plato and Aristotle are not yet literature, either. That is to say, they do not have the sense of faceless depth of the past. These thinkers and writers alone therefore do not suffice for bringing logic into view or to make it a worthy pursuit. Perhaps this is why Aristotle does not have logic as a separate discipline either.

In intermediary sum, literature, logic, and modern hermeneutics of texts are born from a marriage between Homer and Bible which Auerbach helped describe. Logic and literature became rivals and both attempted attracting modern hermeneutics of texts on their respective sides.

\section{Starting Point Two: Temporalities of Suspension}

Let me now no longer use theory to think literature, but instead read literature to think theory. Let me begin, this time not from a theory of literature as before, but from reading a piece of literature, which would help shedding light on the theory. Franz Kafka's short piece, 'Er' ('He') provides a literary articulation of the powers of time Auerbach's theory of literature is dealing with. I will use a short line from the piece as an opening for this section:

He had two opponents. The first besieged him from behind, from the origin [while pushing] ahead. The second denied him any way forward. He fought the both.

['Er hat zwei Gegner: Der erste bedrängt ihn von hinten, vom Ursprung her. Der zweite verwehrt ihm den Weg nach vorn. Er kämpft mit beiden.']

Kafka's character, 'He' as well as the piece, 'He,' is without doubt 'literary' by Auerbach standards, for the text does contain both explicit and inexplicable parts. Gesturing towards the inexplicable, Vivian Liska ${ }^{11}$ asks about the source, the ground, the room, or the power in which or by which 'He' can fight. 'He's' sense of time is remarkably different from both Hermann Cohen's and Martin Heidegger's sense of time - for, in the latter thinkers, time has only one power, the power of the open future, from which time is coming, and which therefore creates its secondary effects, such as past as a necessary virtual starting point and present as no more than a secondary product of that virtual past. For these philosophers, such temporality is of course complex, but quite clear. For Kafka, however, the power of 'He' to fight both the past and the future, and in that sense to suspend the both, remains unthinkable and in that sense unclear in origin.

Despite, and precisely because of this, 'He' provides a helpful starting point to think the suspension, namely to ask about the source of its power.

Walter Benjamin's notion of the power of citation further helps to begin to approximate an inexplicable, and thus 'literary' (Auerbach) part of the suspension at work. To render Benjamin's take on citation, to cite is to destroy. First of all, it means to destroy the past which has never been present by making it present, even if only in the past. In Benjamin, that means to create Niegewesende, or 'that which has never been;' that is to say to bring the past to a closure, following Arendt's interpretation. Even if conceived as fantastic, such cited past is still committing a closure; it still effaces, that is to say both gives face and erases the faceless depth of the past. 'He' thus draws 'He's' power to fight precisely from that destructive side of citation. Citing past He destroys the past's power, and thus becomes able to fight the pressures of the past. Ostensibly, He does the same to the future. At work is a destructive side of citation: it is not only a fulfillment - let alone a substitution of the past by a praesens historicum, and not only an anticipation of the future to come, but also a destruction of the faceless 
past, as well as a destruction of a predictable future. Temporality of such suspension captures that double movement in how NT is suspending OT.

But suspension of OT in NT works in yet other - perhaps less radical but no less crucial - ways:

a. Aufhebung (sublation) in Hegel. That notion both applies to and stems from the concept of NT.

b. Ausnahmezustand (Suspension/Exception from the Law in Schmitt. That notion applies to and again stems from how Paul is read in Church Fathers through the lens of NT).

c. 'Hesitation' in Moses and Paul. In that, I follow Taubes' Rabbinic and anti-Schmittean reading of Paul.

d. 'Subversion' (in Galit Hasan-Rokem's reading of the story of Meir as God and God as Meir in Leviticus Rabbah, of which the Palestinian Talmud has a parallel version to be read slowly in a section below.)

e. Suspension means a spaceless cesura (Agamben): a Catholic and - in Taubes' terms teleological reading of Paul; the caesura leaves room neither to love (which otherwise could undo the teleology of both hope and faith, in Taubes) nor to any resistance to forces moving to a goal, telos, one sets in advance.

f. Suspension means making room for life, for the space of life (Arendt,) which, as already briefly indicated, a philosophic, rather than literary reading of Kafka.

g. Suspension means literature as existence inside and despite the two powers of time, in Vivian Liska's interpretation of Kafka's 'He.'

The staccato of such competing attempts to think the power of citation and thus the power of suspension of OT in and by NT helps to begin to understand both the complexity and the elusive nature of what is at work in suspension of a new testament in the Talmuds, and what can be its temporality and/or structure. That both intimates and makes necessary a new disciplinary framework in which to think the powers of literary citation and of theological suspension together, and through which to draw on these powers in the discipline of philology and its 'powers' (Gumbrecht, again.) That takes me to my third and last starting point.

\section{Starting Point Three: Political Philology ${ }^{12}$ Precedes Political Theology}

I am almost ready to approach the case study at hand. There is one last starting point on the way there. Now it explicitly has everything to do with what I was either implicitly or all too briefly engaging from the very start, with the relationship between political philology and political theology. This is a starting point in a double sense. Here, well into the middle of my argument, I start from a point which takes me to where one should be starting. I start from the discipline of philology and arrive to a thesis that political philology precedes political-theology, including both the literary and philosophical versions of political theology of suspension listed in the staccato above.

It is not only that, as Gumbrecht helps see, philology or curatorship of texts is a political move. It of course is - if not empirically, and even if not conceptually, then foundationally. Philology executes its powers, the 'powers of philology.' Neither is it only that the audience, the on-stage 
characters, the off-stage characters, the writers - and all the multiple audiences the 'texts' articulate, imply, induce, excite, or create - form an aesthetical (and by extension we learn from Kant) ethical stage of action, which the 'powers of philology' are to help to discern. Rather, it is also that the powers and the stage of action of 'texts' belong to what different followers of Kant - from Arendt to Schmitt described as 'the political' - a dimension of the 'curatorship of texts,' which still awaits the attention of scholars.

The political, as one of Kant's followers, Carl Schmitt together with his rabbinically minded radical enemy (that is to say, more than merely an adversary and/or rival) Jacob Taubes ${ }^{13}$ collectively help establish, is all about the form. A form always, of course, comes with content, but a 'political form $^{, 14}$ is such that it tolerates many changes in the content without losing the core of the form, its ability to represent power regardless of any - even mutually exclusive - content it takes. Importantly to what follows, Taubes and Schmitt radically differ in where an individual stands in the works of political form. Schmitt makes an individual insignificant. Taubes, instead, in his analysis of Paul and Moses, pays most close attention to the invisible structure of the inter-personality, even between God and Moses, and surely between Paul and Israel, (which I would not be in hurry to call intersubjectivity,) an inter-personality that comes with the political as a form. In that, in the present argument, I take Taubes' side. The individuality and interpersonality on the stage the Talmudic pericopae induce are all-important, and are still awaiting discernment. ${ }^{15}$

That renders the task of political philology of the Talmuds as the task of paying a much closer attention to the formal structure of the action of the characters in the 'texts' than the 'text-curatorship' afforded so far. One way to arrive to that formal political aspect of philology is to slow down or to turn on the procedure of reading slowly, a procedure that is complimentary for, but not reducible to, either reading closely (Strauss ${ }^{16}$, Wimsatt-Beardsley ${ }^{17}$, Halivni ${ }^{18}$ ) or to reading distantly (Moretti ${ }^{19}$, Septimus ${ }^{20}$ ).

More generally, reading slowly and finding ways, in which to reach a political philology of the two Talmuds also means moving backwards in time, as scholars always did but not always sufficiently accounted for.

The three starting points - literary, hermeneutical, and political - lock in and interlock the case study to follow.

\section{A Case in Suspending the Testified Rules of a Law of 'Suspected Adulteress'}

Political philology thus always precedes political theology. Political theology (exemplified by Schmitt and Taubes as two rival schools) already presumes a political philology. Both Schmitt and Taubes approached NT; they both formulated a political theology as an outcome and the core of how they read NT, for Schmitt, or NT and Mosaic Scripture, for Taubes, in philological terms. Importantly, it is from reading these texts along (Schmitt) or against the grid (Taubes) of suspension of OT in NT that the political theology of these thinkers emerged.

At stake in a political philology that underlies their political theology is the question of where does a rule (as a testimony/testament to the law of the past) stand in regard to that law. It is the problem of law and rule. Can a verbally formulated rule be the law coming from the faceless past and/or can such a rule be the divine law? This question will be also central in the case study below.

In thinking about that general problem of law and rule, my general preliminary thesis is that if the corpora of both the Bavli and the Yerušalmi are considered 'Talmuds,' that is to say internally coherent tractates centered around either the Mišnah (the Bavli) or around other formulations of the law in the rules and/or acts (the Yerušalmi) then a discussion about either their break one from another or their continuity becomes possible, and has already come to fruition. ${ }^{21}$ In contrast, if the Bavli and only the Bavli is axiomatically considered centered on a codified testimony of the divine law, on the code 
called 'Our Mišnah' (מתניתין,) i.e. on a given formulation of the law of the faceless past in the form of a code of rules witnessed in a testimony or testament; and if it is only Bavli's practice to probe and refute but ultimately to defend and thereby remember these codified rules to confirm/establish their status as the second ${ }^{22}$ divine law, the Oral Law of the Mišnah, then the texts of the Yerušalmi can be interrogated differently. That different approach would mean asking: do the compositions in the Yerušalmi either initially or finally approve any testified rules, or do they instead act to suspend any formulations of the law, if it comes in the form of a rule?

The suspension thus (in whichever way it is construed - and how exactly it is in each corpus is a question for future analysis of which I am only making first steps here) is heavily at work in any formulation of law in the form of rules. And this is precisely what is at stake: to suspend any formulation of the law as a rule.

Instructively, in light of this question, the Yerušalmi would display an approach different from either exegesis or isogesis of Mosaic Scripture in midraš. In terms of its political form, that approach is not midraš, because midraš (per Azzan Yadin analysis, for one ${ }^{23}$ ) does not need any second law. Scripture is already the law, but scripture, in the economy of midraš is anything but a formulation/citation of that law in a court. ${ }^{24}$

Instead, at least some places in the Yerušalmi display precisely this: the characters perform the suspension of any formulation of the law in a form of a rule or a set of rules. The tone seems to be (to borrow in advance a theme from the text-study below) 'these are the rules of Sotah-ritual; let's suspend them' in the Yerušalmi, as opposed to 'there are rules the Sotah-ritual, let's defend them and let's show their consistency across the corpus of all the rules in the code and the apocrypha we can get testified,' in the Bavli.

The question then becomes how does the suspension work in the Yerušalmi and what does it represent? Can we just borrow Christian theologeme of suspension of OT in NT to think about how the characters in the Yerušalmi suspend the testified citations of the law in the form of rules and/or acts? Can a Christian theologeme of suspension work for that purpose?

Reading Slowly: the Political Form in the Bavli: the Mišnah as a Testimony of the Law?

Looking at how a testimony is put to a test in the Bavli is a work of a slow reading. I first proceed with a reading of the following record in Sotah 7a:

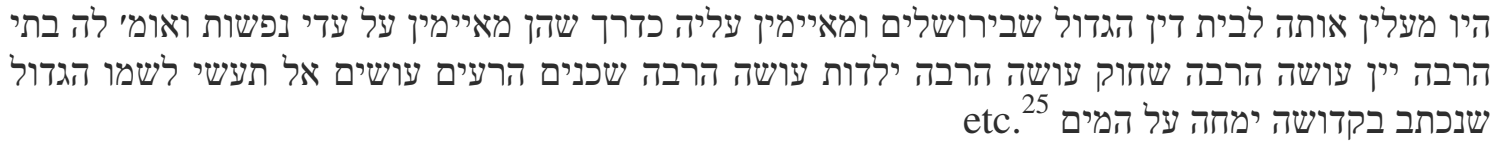

[Mišnah:] They used to bring her up to the great court that was in Jerusalem and admonish her in like manner as they admonished witnesses in capital punishment cases, and they said to her, 'My daughter, much [sin] is wrought by wine, much by light conduct, much by childishness, and much by evil neighbors; do thou behave for the sake of his great Name, written in holiness, so that it be not effaced through the water.' (Danby translation, slightly modified.)

A Tann'a, a mechanical reciter, who is the only type of a witness to offer a testimony of the oral law in a rabbinic court or a rabbinic house of study, offers her testimony. In this case, the law is cited in the form of acts of a court at the time of Jerusalem Temple. The Rabbinic court now turns on, as well. The judges in that latter court, or if one prefers, the students and teachers in the house of study are to decide whether to accept the testimony or to dismiss the witness. Their decision is of course not based 
on ad hominem argument against the personality of the reciter or Tann'a. Just as, in Schmitt's political theology, a personality of a representative of Church or even of a political sovereign is irrelevant in the political form of representation which is all about the dignitary office, rather than about individuality of its bearer, so too is the personality of the reciter. Her personality, in other words, is tellingly irrelevant. The personality of the reciter-witness, as mechanical as her memory might or even is supposed to be, is out of consideration of the judges, who perhaps by the same logic of political representation are the most politically important but surely least embodied characters on the stage. They have no names, and even their number is not explicitly defined. By extrapolation from other Rabbinic texts, the judges can be three, or twenty-one, or even seventy. The judges probe the validity of the testimony by attempting to see if it is refutable and if its defendable against a valid refutation. A general principle of the judges' deliberation articulates more clearly only centuries later, and is therefore only an approximation. In that approximation, however, the principle is as follows. If totally refutable, the testimony becomes invalid and must be dismissed. If totally irrefutable, the testimony must be dismissed as well. The only acceptable testimony is the one that can be both refutable and defendable. That of course might, and de facto does, mean several rounds of probing.

Upon having heard such testimony/testament of the law, the judges, in Sotah 7b deliberate on whether to accept that testimony in the court.

\section{Round 1 A rhetorical question?}

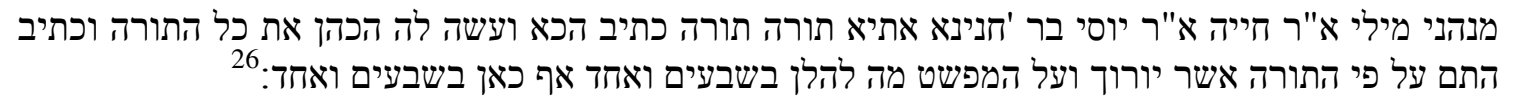

Whence such words? Rabbi Hiy'a said Rabbi Yosi in the name of Rabbi Hanin'a said, there is an analogy between two chapters in the Scripture, each using the term 'torah.' Here [in describing the Sotah ritual in Leviticus 5] it says, 'And the Priest will do to her all the torah...' And there, [in describing other matters judged by the Priests and Levites in Numbers 17] it says, 'according to the torah which they shell teach and according to the judgment.' Just as there it is done in the court of seventy, so too here in the court of seventy.

I will read it slowly. The first round of refuting and defending begins with what is an almost rhetorical question, 'Where these words are coming from? מנהני מילי.' This question would be fully rhetorical if the answer could have come from the judges themselves, i.e. from those on stage. Yet the judges are not entitled to answer for a witness. Instead, an invisible, bodiless, and completely silent agent on stage calls up for another witness, who provides yet another testimony to serve as an answer. According to that testimony, Rabbi Yosi Bar Hanin'a drew an exegetical analogy between two sections in Scripture, one about a priest administering the ritual of Sotah (in Numbers 5, in particular 5:21) and another about a rebellious sage (in Deuteronomy 17:11, where Priests and Levites, in plural, are mentioned as instructing the judgment.)

אתיא תורה תורה...

A judgment by analogy can be derived from a similarity in wording between two verses in the Scripture... 
Rabbi Yosi Bar Hanin'a draw an analogy from a thematically different place in Numbers to the thematically relevant place in Leviticus. The analogy is that just as the rebellious son matters require a full court of 70, so too, the other matters of the Sotah are to be judged in the full court of 70.

(It is quite possible that this analogical judgment of midraš was formulated in a different context and for a different purpose; yet it is clearly cited here to assure the judges on the stage that the suspected adulteress shell be brought to the court in Jerusalem, just as the reciter proscribed.) At any rate, citing Rabbi Yosi Bar Hanin'a downplays the initial refutation - מנהני מילי ('Whence such words?') - by converting it into a merely rhetorical question with an obvious answer - obvious not for the judges yet, but as the readers are to believe, for Rabbi Yosi Bar Hanin'a, of course. That transforms the initial problem into a rhetorical question. In turn, that reduction of a refutation to a rhetorical question concludes the first round and allows the judges to move on to examine other parts of the testimony of the reciter. The best way to undermine an attack on the Mišnah is to convert the attack into a trivial, rhetorical question. The first part of the Mišnah becomes thereby re-approved.

The judges on the stage now move on to the second part of the testimony of the law in the Mišnah, '[the judges] admonish her the way they admonish the witnesses in capital punishment cases.'

\section{Round 2 Testimonies Clash}

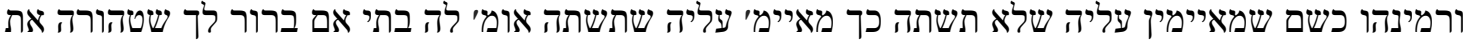

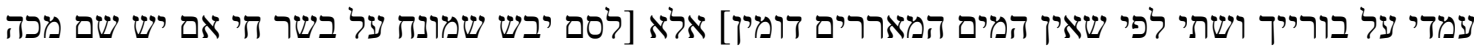

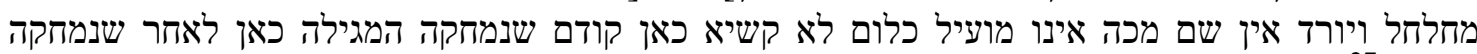

$$
\begin{aligned}
& \text { המגילה }
\end{aligned}
$$

[The judges] called up another reciter. [She recited,] Just as they shell admonish her so that she would not drink [the cursed water] so too they shell admonish her so that she would drink it. They say to her, 'My daughter, if it is clear to you that you are pure, you should stand in front of your creator and drink [the cursed water] for these cursed waters are like a dry poison which is placed on a healthy flesh. If there is a wound, the poison is getting in and down, but if there is no wound the poison has no effect.'

The reader and the judges are to believe now that this was not a valid refutation of the initial testimony in the Mišnah because the Mišnah was referring to a point in the Sotah-ritual before the Holy name is effaced by the water, and the testimony at hand to a point in the ritual after that.

That second attempt to refute the Mišnah was turned on by considering a possible refutation of it. If one objects by calling up another testimony, in which the suspected adulteress is not only discouraged to drink the cursing waters (as the Mišnah had it) but is also encouraged to drink them (as the Mišnah did not), the defense would proceed by claiming the applicability of the Mišnah to an earlier stage in the ritual only, while allowing the other testimony to apply to the ritual in all stages thereof, one by one. That move first of all created and second of all alleviated the contrast between the Mišnah and the other testimony. The judges called up an apocryphal text to counter the precision of the testimony of the reciter at hand. In the previous case, judges could not argue for the testimony and thus needed a citation to be brought in front of them by somebody else. Now, however, they argue against the content of the recited, and this was their procedural right to call up a testimony against a testimony. They thus call up another reciter, i.e. another testimony in order to attack the testimony at hand. That concludes 'Round 2.'

The two rounds already indicate that the discussion in the Babylonian Talmud is centered on the Mišnah as a testified code of the cited law; a conclusion, which is hardly contested in the scholarship on the Bavli. Even if some pericopae in it may not begin as immediate responses to the Mišnah, they 
nevertheless are centered on the Mišnah, and, more specifically on the validity of its testimony, at the end.

The centrality of the Mišnah as a codified testimony of the law in the form of rules and/or acts thus proves to be a formal principle coextensive with the principle of moving through refutations and counter-refutations in the Bavli's discussion. Both are animated by an effort to decide on the acceptability of the Mišnah as a testimony in a version in which it arrives to the court. Despite seeming openness of such an approach, it means a formal-political attempt to validate the testimony of the Mišnah, rather than to dismiss it all together. ${ }^{28}$ For convenience, I term this connection between formal principle of refutation and a no less formal political preference to remember the Mišnah better rather than to have it dismissed 'a principle of Mišnah-centrism.'

It is beyond the scope of this essay to explore further aspects of this Mišnah-centrism by reading the balance of the pericope in question slowly enough to show the dynamic of the relationships between the almost disembodied political characters of the judges on stage and the much more embodied but no less politically necessary number of the off-the-stage characters, such as R. Hiya and Rabbi Yosi Bar Hanin'a. Such reading would describe more specifically the formalism of the political action of the almost bodiless judges on stage, in their pure political form of accepting or dismissing the testimony of the law in its politically complex delivery as a cited law. I therefore stop here and move on to the parallel composition in the Palestinian Talmud.

\section{From Mišnah-Centrism to Suspending New Law (The Political Form in the Palestinian Talmud)}

I am now moving backwards from the Bavli to the parallel pericope found in the Yerušalmi. I had to say 'found in the Yerušalmi' because I am neither attempting to derive conclusions about the Yerušalmi as a whole, nor presume in advance that the Yerušalmi is a whole (such an assumption would be similar to how the authors of Tosafot construed the Bavli to be a tractate of tractates, as coherent within itself as it therefore, for them, had to be.) Instead, I read slowly, rather than either closely or distantly. In this case, it means reading even slower than the implied reader of the parallel pericopae in the Yerušalmi would. That implied reader had so far either read the Yerušalmi as 'just another gemor'ah' that is to say according to the habits and expectations such a traditional reader would have developed in reading the Bavli. In contrast, in reading slowly, I follow, and work against the grain, of the path of the scholarship on the Yerušalmi that moved from the Yerušalmi to the Bavli. In this venue, the scholars argued either that Bavli is radically different, or that what we find in the Bavli is only a further development of that which the Yerušalmi already had. ${ }^{29}$ Yet, unlike this line of scholarship, the path of slow reading proceeds backwards, from a pericope in the Bavli to that in the Yerušalmi, now in order to highlight the formal political - and thus political-philological - difference in the role of not only the Mišnah but also of all Tann'ayitic material in general in the discussion that the almost disembodied on-stage characters in the pericope are performing.

\section{Reading A Palestinian Stage, Slowing Down}

What can a reader say about the nearly disembodied characters on the stage when the flesh and blood characters, such as R. Hiya, or R. Yosi, or R. Chanina in the Bavli composition, are taken as they are, that is as characters off the stage? This path is easier and is already traveled to some extend in the Bavli, including my own exposition above. The Yerušalmi however presents new challenges to the task. This path is much harder to travel when it comes to the stage Yerušalmi presents.

The Yerušalmi arrives to us organized according to the order of the Mišnah, thereby creating an impression that it is also Mišnah-centric. Yet, leaving the question of the positioning of the record 
below in the larger corpus aside, the action in p. Sotah, Folio 4, chapter 1, halakah 4 begins, as it does, without any direct invocation of the Mišnah material.

Rather, the on-stage action begins with an invisible, bodiless and speechless character(s) who summon a Tann'a to recite 'Just as [the priests and/ or judges] are admonishing/coercing/persuading/ her 'to withdraw her claims' of innocence in what her husband alleged her to have committed, ${ }^{30}$ so too they are admonishing/coercing/persuading her not to withdraw such a claim of innocence.' A Bavlioriented reader would assume this testimony would be a gloss or even an attack on the Mišnah, because the Mišnah describes and/or prescribes coercion in one direction only (see the analysis of the Bavli above.) However, there is nothing in the Yerušalmi action on stage to necessitate that assumption.

What is more, the performance on the stage is of a rather different nature - it is not to contrast or cohere between the two testaments of the rules of the same law of the Sotah-ritual, but rather to suspend, although of course not to destroy, the citation of the rule of the priestly Sotah-ritual alltogether. As we will see, it is done on the stage by summoning another testimony, a testimony of an act, the one about what an off-stage character, Rabbi Meir committed.

The invisible, bodiless and voiceless characters on the stage now summon a report, a testimony about acts of a number of the off-stage characters - a story about Rabbi Meir, his female student, and her not-so-well-educated husband, as well as about Rabbi Meir's male students. It is a story of domestic jealousy, and of Rabbinic resistance to allegations made by that not-so-well-educated husband about his wife for having listened to Rabbi Meir's teachings.

The story, which I will immediately translate, is staged in the domain of the priests, in a synagogue, where, nevertheless, a rabbi, not a priest, expounds the scripture. The husband's impatience of and resistance to education in general, or at least to education of a woman, threatens to turn on the priestly ritual of the Sotah.

The story continues to show that it is the noble role of the rabbi to go as far as to humiliate his own honor and/or office publicly in order to turn the ritual off, whatever the testimony of the details of that ritual might be. That, however, once again, does not deny the validity of the ritual, for this is not a concern. The story suggests that it is better to erase the name of a learned sage than to let the priest capitalize on the jealousy of an ignoramus, the husband. At least this is what the implied audience is able to see, that is to say if such an implied audience is not already immersed in the Babylonian concerns about defending the accuracy of the record of the Mišnah.

In terms of form, such staging of the pericopae - from a Tann'ayitic citation to a Rabbinic act performs a suspension of the priestly ritual by a peculiar means of rabbinic self-restrain from executing authority. Again, as we will immediately see, Meir would rather erase his name, and outdo G-d ${ }^{31}$ in that, then humiliate either the wife by the Sotah-ritual or the husband with lashes for suspecting the rabbi of an undue relationships with the wife. This is along the same lines in which, in Taubes, Moses and Paul restrain themselves from assuming any position of direct political leadership. ${ }^{32}$

I arrive to these formulation and conclusions through the following verbal interpretation and analysis of pt. Sotah Folio 4, chapter 1, halakah 4, Sussmann edition, pp. 908-909:

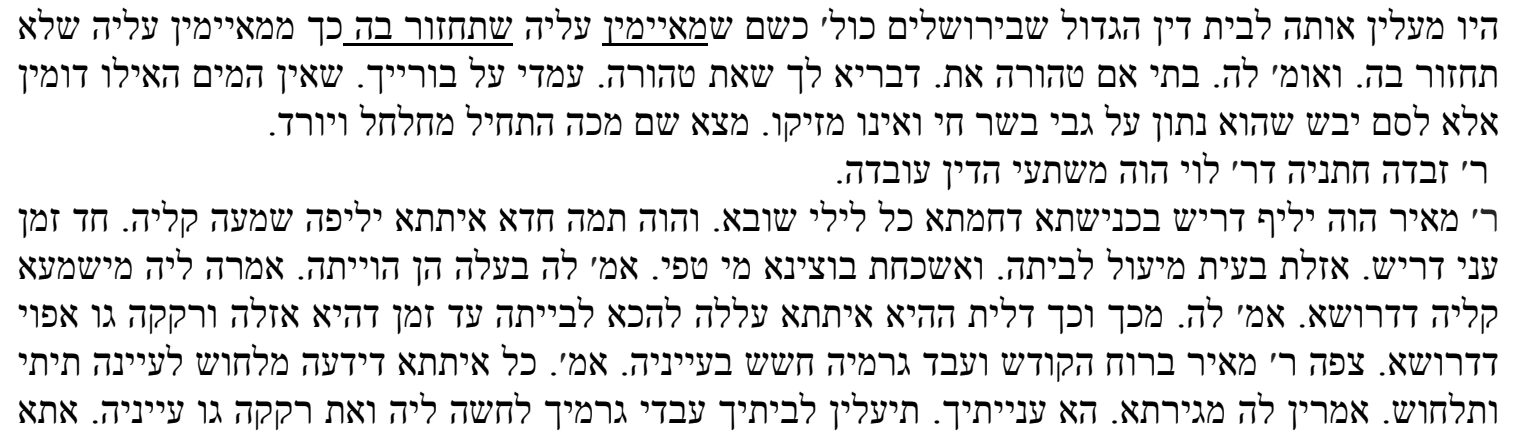


לגביה. אמ' לה. חכמא את מלחוש לעיינא. מאימתיה עליה אמר ליה לא. אמ' לה. ורוקקים בגויה שבא זיה זימנין

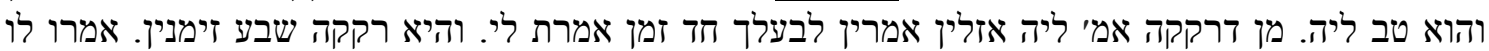

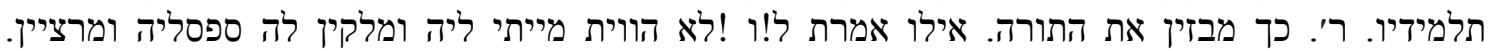

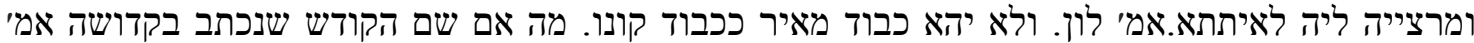
הכתוב שיימחה על המים בשביל להטיל שלום בין איש ואישתו. ובבוד מאיר לא כל שכן.

In Neusner's translation, heavily amended:

[I:1 A] Just as [the judges] admonish her to withdraw [her claim of innocence,] so they admonish

her not to withdraw [it]. And one says to her, 'Now my daughter, if [it is perfectly clear to you that] you are clean, hold to that, and stand before your Creator [ and drink.] For these waters are like a dry salve which is put on living [=healthy] flesh and does no harm, but if there is a wound, it penetrates and goes through.

[I:2 A] R. Zabedeh, son-in-law of R. Levi, would tell the following story.

[B] R. Meir would derive an expounding [from reading the Scripture] in the synagogue of Hammata every Sabbath night. There was a woman who would come regularly to derive from listening to his voice. One evening the expounder struggled with time [i.e. lasted longer than usual.]

[C] She went back home, wanted to enter but found that the flame had gone out. Her husband

said to her, 'Where have you been?'

[D] She replied to him, 'I was listening [in] to the voice of the expounder.'

[E] He said to her, 'May it be such-and-so and even more, if this woman enters my house before she goes and spits in the face of that expounder!'

[F] R. Meir perceived with the help of the Holy Spirit [what had happened] and he developed a boil in his eye.

[G] He said, 'Any woman who knows how to recite a charm over an eye - let her come and heal mine.'

$[\mathrm{H}]$ The woman's neighbors said to her, 'Look at your affliction. Go back home. Prepare the healing mixture, recite charms over it, and spit it in his [R. Meir's] eye.'

[I] She came to him. He said to her, 'Do you know how to heal a sore eye through making a charm?'

[J] She felt admonished and said to him, 'No.'

[K] He said to her, 'Do they not spit into [the mixture or into the eye?] seven times, and it is good for the eye?'

[L] After she had spit in there, he said to her, 'let them go and tell your husband, 'You told her to spit one time, and this woman did seven times!

[N] R. Meir's disciples said to him, 'Rabbi, in such a way do they disgracefully treat the Torah [which is yours]? If you had told us [about the Incident with the husband,] would we not have brought him and flogged her [sic!] at the stock [to bend his will,] until he was [willing to] reconcile with his wife?'

[O] He said to them, 'And should not be the honor of Meir as the honor of Meir's creator? Now if the Holy Name, which is written in a state of sanctification, the Scripture has said is to be effaced with water so as to bring peace between a man and his wife, should not it be even more obvious that the honor of Meir is to be dealt with in the same way!' 
Notably, the disciples of Rabbi Meir resist not only the effacement of Rabbi Meir's title or name. They also, and perhaps more strongly, both resist and share his concern with the applicability of this citation, and by extension any other citations of Sotah-ritual in any form of a testament and/or testimony. That resistance finds an expression in their making Rabbi Meir a clearly absurd proposal in $[\mathrm{N}]$ to have 'brought him [i.e. the husband - S.D.] and flogged her' in order to stop the husband suspecting her in improper relationship with the rabbi. Quite ostensibly the disciples accomplish that by making a parody of the cited Sotah-ritual. The ritual proposed to humiliate the wife in order to deal with the husband's suspicions. To resist that, the disciples sarcastically propose to do even more, to flog her for the same purpose. Although clearly, in the story, Rabbi's Meir's strategy of suspending the ritual wins over his disciples' strategy to take the ritual to an even greater extreme, and thus show it was absurd in the first place. The story thus displays two lines of resistance to a citation of the rule of the law of the past here. One is Rabbi Meir's; another is his disciples'. He is ready to outdo (and protect) G-d by effacing Meir title and name in public. They are ready to show to him that taking the cited rule as seriously as he did leads to absurd. As the story ending makes clear, Rabbi Meir, and with him the strategy of suspending the citation rather than dismissing it as an absurd one wins over.

Comparing with the parallel place in the Babylonian Talmud above, the composition in the Yerušalmi shows no concern with contradictions to the Mišnah (a Bavli concern - in general and in the parallel place Soțh $7 \mathrm{ab}-8 \mathrm{a}$, as above.) But in the Yerušalmi ad locum, there is a concern with limiting the use of the law of the Soțah as it comes in a testimony, either in the Mišnahic one or, as is the case here, in the apocryphal testimony of the law. It is a concern about taking the cited/testified law for the authentic law of the past. This concern is expressed here twice. First of all, it is by offering to go to such a satiric extreme as offering Rabbi Meir to flog the wife to test the firmness of the husband's suspicions against her (that is to say reducing the cited law to absurdity); and second of all, by Rabbi Meir, who is rather taking the cited law seriously enough to suspend it by sacrificing the honor of his office in order to suspend, that is to say neither deny nor apply the cited version of the law of Sotahritual.

The story makes the case for avoiding the Sotah-ritual at all costs, even at the cost of the sage's stripping off from his title (Rabbi Meir becomes Meir) and even at the cost of losing his personal name and dignity (Meir is ready to outdo G-d, in sacrificing his personal name.) On the surface, the sage becomes ready to let his name and title be 'erased' or effaced by public humiliation just as G-d is ready to let His name erased or effaced by water. In both cases the effacement of the name is for the sake of making piece between husband and wife. Yet it also means a sage is willing to humiliate (lit. 'erase' or 'efface' his honor not to get G-d to the point of letting G-d's sacred name written in sanctity to be erased ('wiped out') by the Sotah-ritual, either.

At the bottom, as the on-stage action suggests, the Yerušalmi here is against activating the cited Soțah-ritual on (even in theory) as opposed to, and as a response to the Mišnah and the Barayt'a where this ritual becomes much crueler and much more humiliating as compared to how it is described in the Scripture. Even more importantly, the Yerušalmi here displays a response to presenting the law of such a ritual in the form of a cited rule delivered as a (by definition new) testament in the form of either the Mišnah or the apocrypha. The Yerušalmi thus tames or suspends the citation of the law of the past in the rule.

\section{Conclusion}

To conclude or rather to indicate whereto and how the argument is to continue, the Babylonian and the Palestinian versions of suspending new testament differ one from another. The Babylonian version of suspension is Mišnah-centric. The very efficacy and possibility of witnessing the law as a codified set of rules is accepted, and only the accuracy of these testimonies, however competing and contrasting 
they might be one against another, remains in question. The Palestinian suspension is much more radical: in the case analyzed it suspends all Tann'ayitic materials, apocryphal, and by extension, Mišnahic ones. It thereby suspends any possibility to formulate the law which comes from the faceless depth of the past in a testimony in the form of a rule.

This radical suspension of any testimony of the law that comes from the faceless depth of the past entails a political philology which is suspending - that is both enacts and restrains - the powers of citation. Unlike Kafka's 'He' the power and the direction of that resistance to citing law is not in directing the citation against itself, but rather in suspending the applicability of any citation i.e. of any testament of the law of the past in the first place. The political philology of such a suspension precedes, grounds, exceeds, and escapes the political theology of suspension of one testament in or by another. This is a suspension neither Kafka nor Benjamin nor any other versions of suspending of OT in NT can account for. These thinkers are necessary but not sufficient. They account for the power of citation to foreclose the faceless depth of the past, but they do not account for the power to suspend that foreclosure, a power which the political philology of the Palestinian Talmud helps to discern.

The Rabbinic compositions I read, therefore, are 'literature' in Auerbach's sense, yet the marriage between faceless depth and the façade, between the law of the past and citing it as a present gives birth, in this case, to a different kind of suspension, the suspension of any new testament, that is to say of any testament whatsoever. To that, Auerbach did not - and perhaps programmatically could not - attend; for, his notion of literature follows the lines of a more familiar path of suspension, the suspension of OT by NT. Furthermore, and along the same lines, even if Auerbach had political philology and political theology, his political philology followed his political theology, not the other ways around.

Where, then, does it leave hermeneutics of text vis-a-vis the 'literature' in Auerbach's sense? Does that allow continuing reading the Talmuds under the rubric of hermeneutics of texts? And where can formal logic reside when applied to reading rabbinic texts, if, as oriented to the explication, to the facade, and to the face as it is, that logic claims to be able to read and interpret the facade of a (new) testament/testimony of the law, which however comes, as it does, from the depth of the faceless past?

Can one conceive hermeneutics of text that suspends any testament, rather than taking any testament, and thus any text at its face-value, or according to its formal value, or else as prefigured or otherwise fore-thought by a text that is coming from the imagined before? If logic has, as it conventionally does, anything to do with hermeneutics of texts, the questions become: Can logic either enter in or get out from the circuit of the traditional theologeme of suspending one testament by another? Can one conceive of hermeneutics of texts and/or of formal logic there, where the political philology of suspending any testament is to come first?

\section{References}

1. Auerbach, Erich. Figura. [New York]: [Meridian Books], 1959.

2. Auerbach, Erich. Mimesis: the representation of reality in Western literature. Princeton: Princeton University Press, 1953.

3. Boyarin, Daniel. Socrates and the fat rabbis. Chicago: The University of Chicago Press, 2009.

4. Gumbrecht, Hans Ulrich. The powers of philology: dynamics of textual scholarship. Urbana, Ill: University of Illinois Press, 2003.

5. Harnack, Adolf von, and John Richard Wilkinson. 1925. New Testament studies. VI. The origin of the New Testament and the most important consequences of the new creation. London: Williams \& Norgate, 1925; 
6. Hayes, Christine Elizabeth. Between the Babylonian and Palestinian Talmuds accounting for halakhic difference in selected sugyot from Tractate Avodah zarah. New York: Oxford University Press, 1997

7. Liska, Vivian. Giorgio Agambens leerer Messianismus: Hannah Arendt, Walter Benjamin, Franz Kafka. Wien: 'Schlebrügge.Editor,' 2008.

8. Schmitt, Carl. Political theology: four chapters on the concept of sovereignty. Cambridge, Mass: MIT Press, 1985.

9. Schmitt, Carl, and G. L. Ulmen. Roman Catholicism and political form. Westport, Conn: Greenwood Press, 1996.

10. Septimus, Zvi. The Poetic Superstructure of the Babylonian Talmud and the Reader It Fashions. UC Berkeley: Jewish Studies. [Ph.D. Dissertation], 2011.

11. Strauss, Leo 'How to Study Spinoza's 'Theologico-Political Treatise'. Proceedings of the American Academy for Jewish Research, Vol. 17. (1947 - 1948), pp. 69-131.

12. Taubes, Jacob, and Aleida Assmann. The political theology of Paul. Stanford, Calif: Stanford University Press, 2004.

13. Waite, Geoffrey 'A Short Political Philology of Visceral Reason (A Red Mouse's Long Tail), Parallax, 2005, vol. 11, no. 3, 8-27.

14. Yadin, Azzan. Scripture as Logos Rabbi Ishmael and the Origins of Midrash. Philadelphia: University of Pennsylvania Press, Inc., 2011.

\section{Notes}

1. This essay was first conceived as a contribution for the University of Krakow October 2016 conference on Talmudic Hermeneutics. A part of a further developed version was presented at the Association of Jewish Studies in San-Diego in December 2016. I thank Andrew Schumann for the initial invitation and for organizing the conference in Krakow. I further thank Zvi Septimus, James Redfield, Galit Hasan-Rokem, and Bruce Rosenstock for conversations and discussions of the materials in this essay. I would also like to thank Vivian Liska for a series of conversations that Fall, which have mainly indirectly but no less powerfully informed my argument. Preparation of this paper for publication was made possible with the assistance of funds from The University at Buffalo Gordon and Gretchen Gross Endowed Professorship in Jewish Thought.

2. Similar to a phoneme or morpheme, which are elements contributing to, but not limited to, any particular linguistic expression, for example to a sentence, theologeme is an element contributing to, but not limited to, any particular theology. Thus, the theologeme of NT suspending OT informs a horizon of theologies about NT and OT. Both (1) supersessionism or a Christian view of OT and of Jews as atavism or an obstacle on the way to accepting NT, and (2) denial of supersessionism of OT as having been never abrogated and still true for the Jews, as mutually exclusive as these two positions are, still belong to the same horizon of Christian theological thinking. The following formulation of Harnack helps illustrate how the theologeme of suspension tacitly informs that horizon. In his outline of 'motives" leading to creating the New Testament as a document, Harnack writes, 'The third motive belongs ... to Saint Paul and to those who learned from him. It finds expression in such words as these: "Christ is the end of the Law," "The Law is given by Moses, Grace and Truth came through Jesus Christ," and the like. Pauline Christians, and many that were not Pauline, were convinced that what Christ has brought with him, in spite of His connection with Old Testament, was something "new" and formed a "New Covenant." The conception of the "New Covenant" necessarily suggested the need for something of the nature of a document; for what is covenant without its document?" (Harnack, Adolf von, and John Richard Wilkinson, 1925; p. 12-13.) The 'in spite" in Harnack's formulation is the key of suspension. To wit: To be 'convinced" "in spite of His connection with Old Testament" i.e. with Scripture that Messiah's life and death in Gospels is a record of New Covenant of Grace and Truth is automatically and tacitly positing the canonical Scripture to have become "old." That positing happens before and predetermines "the motive," which Harnack outlines. The motive is always already a fulfillment of that tacit positing. This is why Harnack's explanation of the motive is both necessary and insufficient. Missing is the recognition that the new creates the old, a recognition of the theologeme of suspension at work here. The formal theologeme of the "new" creating the 'old" came before "the motive." The latter was only a concretization of that theologeme in a concept, or rather in several, even mutually exclusive ones. 
Supersessionism or the idea that NT makes OT atavism is one such concretization. Denial of supersessionism is another. Yet they both stem from one and the same non-linear theologeme of suspension, and both attempt to concretize that theologeme in a linear way.

3. Cf., for one: Schmitt 1985.

4. See Waite, 2005.

5. See: Auerbach, 1953.

6. Cf.: Auerbach, 1959 .

7. I follow the volume's standard of Hebrew characters transliteration, except for common terms, such as midraš and Yerušalmi, which are already coined in their English spelling.

8. Idem.

9. Gumbrecht, 2003.

10. By way of a contrasting clarification in passing, according to Auerbach that would be not only and not simply about the past that has never been present, but even about that past that has no face.

11. See an analysis of these lines by Kafka in: Liska, 2008. I am also citing Kafka from this edition.

12. I am following and, to say the least, extending the notion of political philology articulated by Geoffrey Waite, 2005: vol. 11 , no. 3, 8-27. pp.

13. Cf.: Taubes, Jacob, and Aleida Assmann. 2004.

14. The term comes from Schmitt, 1996.

15. I have begun working in this direction in my forthcoming The Political in the Talmud (Fordham U. Press, 2017) where I addressed Carl Schmitt, but not Jacob Taubes.

16. Leo Strauss 1947-48; pp. 69-131.

17. W.K. Wimsatt, Jr., and Monroe C. Beardsley. 1954.

18. Halivni, Daviid. 2012.

19. Moretti, Franco. 2015.

20. Septimus, Zvi. 2011.

21. I refere here to scholarship on comparative study of the two Talmuds beginning from Saul Lieberman and continuing to its implementation in Christine Hayes, where Yerušalmi is considered to be foreshadowing Bavli. See the analysis and bibliography in Hayes, 1997.

22. The question of the Mišnah as "second law" becomes even more interesting and more important, if thought of in view of Greek dismissal of any articulated law as inferior to any divine law. The latter is immediately given to humans, the former takes human articulation either in writing (Scripture) or in speech (Recitation of the Mišnah by heart). Both would be secondary to the Greeks, an approach Antigone, who insisted on preferring diving unspoken and unwritten law to the man-made edict of Creon, can clearly illustrate. In this perspective both Scripture and the Mišnah are secondary, even if such an approach misses the style of Mosaic Scripture, in Auerbach's term, i.e. misses the faceless depth of the past, by thinking face can mean law immediately, before one writes, reads, and/or memorizes.

23. Yadin, Azzan. 2011.

24. In that way, midraš as an approach to Scripture, can escape any 'Greek" dismissal of Scripture as a formulation of law in a rule.

25. Kaufman A 50.

26. Vatican Ebr. 110-111.

27. Ibid.

28. See: Boyarin, Daniel. 2009.

29. Hayes, Christine Elizabeth. 1997.

30. You will note the difference with the Bavli version, where it is about to admonish her "not to drink" and then "to drink."

31. See the analysis of the narrative by Galit Hasan-Rokem at: Hasan-Rokem, Galit. 2003.

32. Notably, but also beyond the immediate scope of this essay, Jacob Taubes reads both Paul and Moses, relying as he is, upon rabbinic midraš in order to highlight Moses suspending God's wrath against Israel. 